\title{
Penelusuran Literatur Dalam Penulisan Artikel
}

\author{
Ismail Suardi Wekke \\ Sekolah Tinggi Agama Islam Negeri (STAIN) Sorong \\ Email: iswekke@gmail.com
}

\begin{abstract}
ABSTRAK
Literatur yang dirujuk dalam proses penulisan ilmiah merupakan bagian utama dari karya tersebut. Bukan hanya sebagai pemanis belaka, atau unsur yang dapat diabaikan dalam proses pembacaan karya ilmiah. Keberadaan literatur akan menjadi pendukung dalam menunjukkan bahwa artikel tersebut merupakan kelanjutan dan kesinambungan dari publikasi yang sudah ada sebelumnya. Artikel ini mengidentifikasi syarat sebuah literatur yang dapat dijadikan sebagai rujukan dalam proses penulisan ilmiah. Selanjutnya, artikel ini juga menggambarkan aspek utama dalam penulisan laporan penelusuran kepustakaan.
\end{abstract}

Kata Kunci: literatur, penelusuran, daftar pustaka

\section{Pendahuluan}

Sebuah temuan yang menjadi presentasi dalam artikel perlu didudukkan dalam konteks keilmuan. Bisa saja apa yang ditemukan dalam artikel yang sementara ditulis sesungguhnya sudah tersaji dalam penerbitan sebelumnya. Bahkan itu sudah menjadi pemahaman awam bagi kualifikasi kesarjanaan. Dalam semua rumpun keilmuan, ada syarat minimal penguasaan keilmuan seorang sarjana dalam penyelesaian studi. Tidak ada toleransi terhadap ketidaktahuan hanya karena tidak cermat menelusuri tema-tema yang terkai dengan pokok bahasan yang sementara dikaji. Ketika itu terjadi, maka justru kritik akan muncul terhadap karya yang dihasilkan (Dunlop, 1998).

Dengan menguasai itu, sebuah tanda bahwa sarjana sudah menguasai pemahaman dasar yang dibutuhkan untuk berbicara dalam konteks keilmuan dalam bidang tersebut. Memisahkan sebuah pembahasan dari keeratan dengan gambaran umum ilmu pengetahuan, pada akhirnya tidak akan bermakna apa-apa. Padahal, sejatinya aktivitas keilmuan dalam rangka turut dalam memberikan gambaran utuh penjelasan alam dari hasil kerja-kerja empiris. Melalui telaah pustaka, akan didapatkan detail dari karya-karya sebelumnya untuk menjadi wawasan bagi penulisan selanjutnya (Cahyono \& Wekke, 2018). Proses keilmuan di masa lalu, perlu dikaitkan dengan aktivitas akademik saat ini. Apa yang dihasilkan pada era sebelumnya, akan diperkuat atau justru dapat saja ditolak karena konteks yang berbeda. Sebuah temuan ilmiah yang dapat 
bertahan sampai sekarang menunjukkan kebenaran pengetahuan. Menempatkan kajian literatur merupakan upaya dalam ikut serta dalam percakapan ilmiah yang sudah berlangsung seumur dengan usia manusia itu sendiri (Chatterjee-padmanabhan, Nielsen, \& Sanders, 2019). Ini akan memperkuat kerangka konspetual yang sementara dibangun untuk menunjukkan posisi kajian yang sementara dijalankan.

Pada beberapa kasus, kadang itu terabaikan. Ketika ini terjadi, maka paparan temuan yang dikemukakan sesungguhnya bukan sesuatu yang baru sama sekali. Hanya karena ketidaktahuan penulis atau ketidaklengkapan pembacaan terhadap tema yang dibahas. Sehingga tidak menyajikan temuan sebelumnya. Atau waktu yang digunakan untuk menelusuri literatur belum memadai. Sehingga menghubungkan antara satu temuan dengan temuan yang lain tidak dapat dilakukan. Untuk itu, diperlukan identifikasi literatur yang komprehensif untuk menghindari kekeliruan ini (Hart, 2001). Sekaligus menggambarkan bahwa apa yang dihasilkan dalam publikasi ini merupakan kerja yang menyeluruh. Ini dapat dilakukan dengan mengadakan komunikasi secara intensif dalam multidisiplin keilmuan. Sekaligus sebagai cara untuk mempertahankan integritas keilmuan. Penulis bertanggungjawab melakukan paling tidak tiga hal yaitu memilih kepustakaan, merangkum intisari maklumat, dan merujuk dengan cara yang patut (Gasparyan, Yessirkepov, Voronov, Gerasimov, Kostyukova, \& Kitas, 2015).

Tidak saja kesilapan tetapi juga menghindari pengulangan. Apa yang sudah ada, kemudian disajikan kembali tanpa penambahan sesuatu yang baru, kemungkinan akan membawa kepada kesia-siaan. Dengan adanya penelusuran literatur, jawaban-jawaban atas pertanyaan penelitian yang sudah dipublikasikan dapat dipetakan. Bisa saja menjadi jawaban sementara (hipotesa) namun dengan adanya data yang komprehensif, ini akan menjadi sebuah gambaran dalam skala yang lebih besar. Karya ilmiah dibentuk dalam sebuah rangkaian data. Tidak saja dengan temuan awal yang disangka menjadi penopang pengetahuan. Bahkan bisa jadi sebuah andaian demi andaian akan menjadi rangkaian tersendiri dalam membentuk kekokohan bagunan ilmu pengetahuan (Brew, \& Wekke, 2018).

Konteks keilmuan atau bangunan sains menjadi gambaran mikro setiap bidang kajian. Kemudian dalam konteks makro ilmu pengetahuan, ada hubungan saling terkait di setiap bidang keilmuan. Diperlukan pemahaman komprehensif sehingga setiap peneliti mampu memberikan kontribusi bagi pengembangan keilmuan. Selanjutnya diteruskan dalam bentuk metodologis. Tidak saja dalam kerangka menemukan masalah penelitian, tetapi secara sistematis dapat 
dipetakan konsep keilmuan dan gambaran publikasi yang sudah wujud sebelumnya. Dengan demikian, sebuah publikasi terbaru juga mengemukakan aspek kebaruan. Bukan sebaliknya publikasi terbaru justru memunculkan wawasan yang sudah usang, semoga saja bukan

pembahasan yang sudah basi. Jika itu terjadi, tidak saja dihindari. Bahkan dijauhi karena akan menjadi bacaan yang tidak berguna atau bahkan sama sekali tidak diperlukan. Pada tahapan tertentu bisa saja merusak.

Menulis dalam konteks makro tidak saja menjadi keperluan di perguruan tinggi. Justru ketika berada di perguruan tinggi, menulis secara makro dilatihkan. Sehingga saat terjun ke masyarakat, ini akan menjadi bekal dalam mengarungi kehidupan yang sesungguhnya justru merupakan bentangan fenomena. Alumni perguruan tinggi Amerika menyatakan bahwa kemampuan menulis dalam lingkup lebih luas akan menjadi latihan dalam menuangkan gagasan sekaligus melakukan verifikasi terhadap kondisi faktual (Gere, 2019). Kecermatan dalam menjalankan penelusuran literatur terkait pula dengan kualitas tulisan (Dunlop, 1998). Maka, sejak awal dalam menelusuri literatur yang terkait dengan tema yang sementara ditulis sesungguhnya merupakan proses yang sama pentingnya dengan keseluruhan aktivitas yang dilaksanakan dalam kajian ilmiah. Gambaran komprehensif yang akan dipotret dalam aktivitas penelusuran literatur adalah state of the art. Sejatinya, menelusuri literatur adalah aktivitas untuk menemukan gambaran kondisi mutakhir perkembangan ilmu pengetahuan. Penulis memiliki kesempatan untuk menuangkan seluruh imajinasi keingintahuan dalam kerangka konseptual (Hart, 2018). Selanjutnya, dengan menelusuri literatur, penulis akan menemukan gambaran makro atau bangunan diskursus akan topik tertentu yang sementara dipelajari. Gambaran yang dikemukakan ketika itu semakin detail, akan semakin bagus (Wekke, 2017).

\section{Syarat Literatur yang Dirujuk}

Alwasilah (2015) mengajukan pertanyaan terkait dengan kajian pustaka antara lain yaitu penelitian apa sajakah yang mengilhami penelitian anda?, kapan sumber itu diterbitkan?, sejauh apa kemantapan sumber itu?. Tiga pertanyaan tersebut menjadi bagian dari syarat dalam menggunakan sebuah literatur. Kekurangcermatan memilih pustaka menjadi titik lemah sebuah proses penelitian.

Dalam menggunakan literatur, tidak semua terbitan baik dalam bentuk cetakan maupun versi daring (online) yang tersedia dapat digunakan begitu saja. Melainkan perlu kecermatan 
untuk memilah kondisi literatur itu sendiri. Kesilapan penggunaan literatur akan mengganggu dan bahkan bisa saja menjadikan karya akademik yang ditulis tercemar atau bahkan ditolak. Dengan melihat referensi yang dijadikan sebagai bacaan awal akan memberikan kepercayaan pembaca terhadap sebuah artikel. Untuk itu, sejak awal perlu dilakukan seleksi sebelum menggunakan sebuah literatur. Sebelum sampai pada seleksi mengidentifikasi literatur tersebut dengan menyeleksi berdasarkan kriteria yang ditentukan sesuai dengan keilmuan masing-masing. Syarat utama literatur yang digunakan, wajib relevan dengan kajian yang akan dilaksanakan (Kennedy, 2007).

Referensi yang tersaji bisa jadi tidak memenuhi unsur keilmuan. Hanya sebagai informasi awal semata. Atau bahkan sebagai sajian jurnalistik sebagai jawaban atas keingintahuan publik untuk satu kawasan dan tempo tertentu saja. Tetapi itu, belum memenuhi syarat ilmiah secara lengkap. Sehingga tidak dapat digunakan untuk menjadi rujukan. Maka, syarat pertama yaitu validitas maklumat. Jangan sampai itu merupakan informasi yang tidak valid. Ketika mendapatkan sebuah informasi atau hasil kajian tertentu, maka perlu dikonfirmasi dengan temuan yang lain. Tidak ada temuan yang spektakuler atau satu-satunya di dunia. Sebab ilmu pengetahuan tak menyimpan rahasia apapun. Semua informasi tersedia dengan lengkap dan dapat diakses oleh siapapun juga.

Untuk memenuhi validitas referensi, maka sumbernya juga harus terpercaya. Kredibilitas, menjadi syarat kedua bahwa literatur idealnya merupakan informasi yang kredibel, berasal dari tangan pertama (primer). Sebuah data yang sifatnya sekunder memungkinkan terjadi kesilapan dalam merujuk sehingga tidak dapat diandalkan. Ada kemungkinan sitiran yang keliru jika hanya tersedia pada sumber kedua (sekunder). Jika ini salah, maka apa yang dirujuk oleh penulis melalui sumber kedua itu akan ikut salah juga.

Sumber-sumber primer ilmiah melalui proses review baik secara internal maupun eksternal. Sehingga sudah melalui proses ilmiah yang bertingkat. Sehingga penggunaan wiki atau blog tidak dapat dijadikan sebagai referensi. Penyusunan wiki maupun blog dilakukan secara simultan dan bisa saja berubah setiap saat. Secara khusus, wiki merupakan kumpulan informasi yang dinamis. Ada saja informasi yang dapat ditambahkan dan juga disunting oleh siapa saja. Penyusunan wiki tidak memerlukan kepakaran tertentu. Karena keduanya memungkinkan untuk dilakukan penyuntingan kapan saja oleh penulisnya. Demikian pula, informasi ini bisa saja hilang setiap saat karena dihapus oleh penulisnya. Sebagai informasi awal 
untuk memandu penelururan lebih luas, keduanya dapat saja digunakan. Pengumpulan maklumat dari wiki maupun blog dapat dilakukan untuk memandu pada penjejakan sumber-sumber informasi lainnya. Tetapi untuk dirujuk, maka tidak dapat digunakan sama sekali. Ini berkaitan dengan keterpenuhan unsur-unsur yang berkenaan dengan kredibilitas.

Salah satu sumber primer yang perlu dirujuk adalah jurnal. tidak saja valid tetapi juga kredibel. Sebuah artikel jurnal sudah melalui proses review bahkan dilakukan tidak kurang dari dua orang. Setelah sebelumnya sudah melalui seleksi internal (editor). Proses selanjutnya juga melalui penyuntingan sampai pada penerbitan. Informasi yang disampaikan dalam sebuah artikel selalu mutakhir, walaupun isu lama tetapi dengan data yang terbaru. Dengan dasar ini, maka menggunakan artikel jurnal merupakan bagian utama dalam mendukung pelaksanaan riset.

Perlu pula dibedakan antara data dengan referensi. Untuk sebuah data, dapat ditemukan dari mana saja. Bahkan usia data semakin lama akan semakin bagus, terutama terkait dengan kajian ilmu tertentu. Namun, referensi sebaliknya. Semakin mutakhir semakin bagus. Ini untuk menjadi penanda bahwa analisis yang dituliskan merupakan kajian terkini. Sekali lagi, bukan merupakan pengulangan demi pengulangan. Ada perbedaan fungsi antara data dan referensi. Data digunakan untuk memperkuat hasil penelitian. Sementara referensi untuk menunjukkan state-of-the-art dan juga memperkuat temuan dalam pembahasan penelitian. Keduanya digunakan secara terpisah, sehingga masing-masing berada di tempat yang berbeda.

Terakhir, kemutakhiran referensi. Semakin baru sebuah rujukan akan semakin bagus. Ini menunjukkan bahwa artikel yang sementara ditulis mengikuti perkembangan keilmuan. Tidak lagi menggunakan data-data lama bahkan sudah usang dan tidak lagi dijadikan rujukan. Menulis artikel tidak terkait dengan teori. Kerap muncul pertanyaan "bagaimana posisi teori dalam sebuah artikel?". Bisa saja, teori dituliskan dalam bagian pendahuluan untuk menggambarkan state-of-the-art. Tetapi tidak diperlukan dalam rangka menunjukkan konteks pembahasan. Apalagi kalau hanya sekadar menjadi pemanis belaka. Penggunaan teori dimungkinkan jika dalam artikel tersebut perlu dikemukakan adanya sebuah teori. Tetapi jika dihilangkan, dan tidak menggangu sama sekali pokok bahasan, maka sebaiknya dihilangkan saja. Pembahasan sebuah teori berada dalam tipikal buku referensi. Bukan pada gaya penulisan artikel jurnal.

Perlu juga memperhatikan rekomendasi asosiasi profesi keilmuan. Kadang organisasi profesi memberikan rekomendasi definisi tentang waktu kebaruan sebuah artikel. Setiap bidang 
keilmuan berbeda dalam mendefinisikan kemutakhiran bahan pustaka. Kajian eletronika, berbeda dengan kajian teknik sipil. Apalagi dengan studi agama.

Kesemuanya dimungkinkan jika sejak awal peneliti memiliki sikap ilmiah. Ini yang akan menjadi sensor awal untuk melihat keadaan sebuah referensi. Syarat sebagai peneliti, harus menjadikan diri sebagai penyaring awal. Pendekatan kualitatif bahkan menjadikan peneliti sebagai intsrumen penelitian. Sejak awal ketika menelusuri literatur, jika itu sudah memenuhi semua kriteria yang dipersyaratkan menjadi sebuah produk ilmiah. Sikap ilmiah juga berkaitan dengan integritas akademik penulis. Salah satu bagiannya adalah etika penulisan dengan senantiasa mengedepankan kejujuran akademik dalam seluruh proses penulisan (Ardinansyah, Tenrisau, Aslim, \& Wekke, 2018,). Namun ini tidak cukup hanya pada etika semata. Integritas akademik mencakup keseluruhan dari proses penulisan artikel (Macfarlane, Zhang, \& Pun, 2014). Tidak sebatas pada persoalan literatur semata.

Termasuk dalam soal sikap adalah ketelitian. Referensi yang digunakan perlu dicek berulang kali. Perlu membedakan setiap referensi yang ditemukan. Jangan sampai, merujuk kepada publikasi yang masih sementara dalam tahap usulan ataupun dilakukan sebagai tahp awal penelitian. Maka, perlu dipetakan bagaimana sebuah penelitian yang sudah dilakukan. Kemudian dibandingkan dengan temuan penelitian dalam skala yang luas. Demikian pula ketika digunakan dalam penulisan. Setiap gaya penulisan memiliki ciri khas tersendiri. Ketika mengikuti gaya selingkung penulisan artikel, penulis perlu taat dan teliti dalam penggunaan gaya tersebut. Ini dapat dibantu dengan menggunakan perangkat teknologi informasi seperti Mendeley atau Zotero. Terdapat pula alat lain yang dapat digunakan penulis untuk membantu produktivitas penulisan ilmiah (Nur, Sabara, \& Wekke, 2018). Ketelitian dalam penggunaan referensi ditunjukkan dengan keakuratan semua informasi dalam setiap pustaka yang dirujuk. Disesuaikan dengan tipikal masing-masing naskah. Setiap naskah memiliki maklumat yang berbeda-beda. Semua referensi yang digunakan sebagai rujukan dalam penulisan artikel, wajib tersaji dalam daftar pustaka. Penulisan daftar pustaka sepenuhnya hanya pada referensi yang dirujuk. Jangan sampai ada referensi yang dicantumkan dalam artikel tetapi tidak terdapat dalam senarai daftar pustaka. Ini perlu dicek kembali. Sehingga sebuah manuskrip sebelum dikirimkan untuk penerbitan sudah mengalami pengecekan kembali untuk memastikan keakuratan penulisan sesuai dengan ketentuan yang disyaratkan (Kirchhoff, 1995). Jangan sampai masih terjadi kesilapan baik dalam pencantuman maupun penyebutan referensi. Penelitian tentang manuskrip menunjukkan bahwa 
dari 261, setidaknya terdapat satu masalah baik dalam hal penulisan maupun dalam tata cara merujuk (Browne, Logan, Lee, \& Torreggiani, 2004).

Jikalau ini terjadi, maka akan menjadi kekurangan artikel tersebut. Bukan untuk menjadi saran bagi pembaca dalam memperkaya literatur yang perlu dibaca sebagai kajian lanjutan. Itu disebut dengan bibliografi. Disyaratkan dengan tiga kriteria yaitu akurat, lengkap, dan konsisten (Nicoll, Oermann, Chinn, Conklin, Amarasekara, \& McCarty, 2018). Tidak saja terkait pada memilih sejak awal bacaan yang akan digunakan sebagai rujukan tetapi juga menuliskan kembali secara akurat (Bavdekar, 2016). Sebuah artikel yang dirujuk setidaknya dapat ditemukan kembali oleh pembaca (Maisonneuve, 1994), jangan sampai naskah tersebut merupakan naskah yang tidak dipublikasikan untuk umum. Presentasi lisan, manuskrip yang sementara disunting, dan komunikasi personal yang tidak dapat diakses publik, menjadi referensi yang tidak layak untuk dirujuk untuk dijadikan bagian publikasi.

\section{Aspek Utama Laporan}

Empat langkah dalam menelesuri literature secara sistematik diperkenalkan Schweizer \& Nair (Schweizer \& Nair, 2017). Pertama, menemukan. Saat ini dengan bantuan teknologi komunikasi, menelusuri literatur menjadi aktivitas yang menyenangkan. Tidak lagi membosankan dengan mengecek satu persatu kertas katalog dengan tulisan yang tidak semua orang dapat membacanya dengan jelas. Keberadaan teknologi informasi memberikan kemudahan bagi sapa saja, bahkan dapat disesuaikan dengan keperluan masing-masing individu. Untuk menemukan literatur yang sesuai dengan kajian artikel yang ditulis dapat menggunakan platform seperti Google Cendekia. Semakin spesifik kajian yang dijalankan semakin memerlukan laman web yang juga spesifik.

Selanjutnya, mengevaluasi. Literatur yang ditemukan tidak semuanya dapat digunakan begitu saja. Maka, kepustakaan itu perlu dievaluasi minimal pada dua aspek yaitu validitas dan kredibilitas. Hanya bacaan yang tepat dapat dirujuk untuk dijadikans ebagai referensi penulisan artikel. Berikutnya, sintesa data. Data-data yang sudah dievaluasi dimasukkan dalam kategorikategori tertentu sesuai klasifikasi tema. Data tersebut setelah dianalisis kemudian digabungkan dengan data lain. Sehingga rujukan pada sebuah tema tidak hanya didasarkan pada data tunggal melainkan merupakan gabungan antara beberapa data. 
Keempat, menuliskan manuskrip dengan bentuk meta analisis. Laporan yang ditulis bukan dalam bentuk paparan kepustakaan saja. Bahkan harus lebih terbatas lagi dalam bentuk meta analisis saja. Gaya penulisan artikel akan berbeda sama sekali dengan pola bertutur terutama dalam khutbah atau ceramah keagamaan. Maka, mengemukakan data yang dirujuk dalam sebuah literatur tidak perlu menjelaskan keseluruhan unsur sebuah buku atau artikel. Tetapi hanya mempresentasikan informasi yang dibutuhkan dalam keeratan dengan pokok bahasan. Adapun data mengenai judul dan maklumat selengkapnya, dapat ditemukan oleh pembaca dalam senarai pustaka yang diletakkan di bagian akhir artikel. Atau mengikut kepada gaya selingkung penulisan artikel dalam sebuah jurnal. Informasi yang dikemukakan dalam kaitan dengan sebuah literatur terbatas pada salah satu atau semua hal dari kesimpulan utama dari temuan, dan kesimpulan mengenai persoalan yang dikaji (Knopf, 2006).

Penelusuran literatur tidak hanya sekadar membaca dan kemudian menuliskan publikasi yang sudah ada. Menelusuri literatur juga terkait dengan melaporkan publikasi tanpa hadirnya bias sama sekali. Justru dengan laporan publikasi yang ada akan menjadi pendukung terhadap kondisi yang wujud. Demikian pula wajib adanya perspektif penulis terhadap bukti-bukti yang diajukan. Interprestasi data dan penilaian terhadap kualitas data menjadi langkah dalam mengurangi bias dari kajian yang dilaksanakan.

Berhati-hati terhadap proses penulisan dengan memperhatikan bagian yang harus disitasi. Jangan sampai pendapat orang tidak dirujuk selayaknya. Termasuk membedakan mana pendapat penulis dengan pendapat yang merupakan hasil bacaan dari kepustakaan yang ada. Perlu dicatat setiap bagian yang diambil dari hasil bacaan. Selanjutnya memberi komentar atau pendapat terhadap apa yang dipaparkan (Winchester \& Salji, 2016). Juga, sebuah laporan semata-mata tidak hanya memuat pendapat para pakar saja. Sehingga laporan menjadi daftar pendapat dari para sarjana. Namun nihil dari ulasan atau analisis dari penulis secara pribadi. Pendapat pakar itu perlu mendapat komentar, sesuai dengan konteks penulisan literatur yang dilakukan. Ketika pendapat pakar dirujuk dan menjadi bagian tulisan (Brooks-Brunn, 1998), sepenuhnya sudah persetujuan penulis.

Satu hal lagi yaitu wawasan. Untuk melihat aspek ini, maka semakin komprehensif sebuah artikel akan berarti horizon yang disampaikan akan semakin luas (Wibowo, 2013). Dalam kriteria artikel wawasan dapat dipetakan menjadi lokal, nasional, regional, dan global. Keempat kategori itu juga dapat menunjukkan tujuan penerbitan sebuah artikel. Penelitian dapat saja 
dilakukan secara lokal dalam sebuah studi kasus. Namun, wawasan yang dikemukakan dalam bagian pendahuluan dan pembahasan bisa wujud dalam skala global. Aspek tersebut terlihat dalam penggunaan literatur yang disenaraikan dalam daftar pustaka. Bisa dilihat kepelbagaian penulis dan juga cakupan geografis penelitian dan penerbitan yang dijadikan sebagai rujukan.

\section{Penutup}

Terdapat dimensi lain dalam proses penulisan artikel yang tidak terkait hanya pada urusan akademik semata. Di luar wilayah kampus, dimensi sosial akan mendominasi. Sehingga kemampuan untuk mengenali literatur sampai menggunakannya, juga diperlukan dalam kehidupan yang tidak terbatas pada bangku kuliah semata. Maka, menggunakan literatur sesungguhnya adalah merupakan proses perlu dikuasai, bukan saja untuk keperluan dalam urusan perkuliahan. Melainkan juga akan dipergunakan pada saatnya dalam aktivitas keseharian yang tidak terkait sama sekali dengan kegiatan akademik sekalipun.

\section{Daftar Pustaka}

Alwasilah, A. C. (2015). Pokoknya studi kasus pendekatan kualitatif. Bandung: Kiblat Buku Utama.

Ardinansyah, A., Tenrisau, D., Aslim, F., \& Wekke, I. S. (2018, July 21). Ketidakjujuran Akademik Dalam Pendidikan Tinggi. https://doi.org/10.31227/osf.io/tp9vg.

Bavdekar, S. B. (2016). Enhance the value of a research paper: Choosing the right references and writing them accurately. Journal of The Association of Physicians of India, 64, 66.

Brew, A., \& Wekke, I. S. (2018). Hakikat Karya Ilmiah (The Nature of Research). Deepublish.

Brooks-Brunn, J. A. (1998). How and when to reference. Nurse author \& editor, 8(2), 1-4.

Browne, R. F., Logan, P. M., Lee, M. J., \& Torreggiani, W. C. (2004). The accuracy of references in manuscripts submitted for publication. Canadian Association of Radiologists Journal, 55(3), 170.

Cahyono, D., \& Wekke, I. S. (2018). Teknik Penyusunan dan Penulisan Tesis. Deepublish.

Chatterjee-padmanabhan, M., Nielsen, W., \& Sanders, S. (2019). Joining the research conversation: threshold concepts embedded in the literature review. Higher Education Research \& Development2, 38(3), 494-507. https://doi.org/10.1080/07294360.2018.1545747.

Dunlop, A. (1998). Using research methodology to explore quality of social interaction. European Early Childhood Education Research Journal, 6(1), 87-104. https://doi.org/10.1080/13502939885208181.

Gasparyan, A. Y., Yessirkepov, M., Voronov, A. A., Gerasimov, A. N., Kostyukova, E. I., \& Kitas, G. D. (2015). Preserving the integrity of citations and references by all stakeholders of science communication. Journal of Korean medical science, 30(11), 1545-1552.

Gere, A. R. (2019). Writing beyond the university. In Developing Writers in Higher Education (281-311).

Hart, C. (2001). Doing a literature search: a comprehensive guide for the social sciences. Sage. 
Hart, C. (2018). Doing a literature review: Releasing the research imagination. Sage.

Kennedy, M. M. (2007). Defining a Literature. Educational Researcher, 36(3), 139-147. https://doi.org/10.3102/0013189X07299197.

Kirchhoff, K. T. (1995). Ensuring accurate references. Nurse author \& editor, 5(1), 1-3.

Knopf, J. W. (2006). Doing a literature review. PS: Political Science and Politics, 39(1), 127132.

Macfarlane, B., Zhang, J., \& Pun, A. (2014). Academic integrity: a review of the literature. Studies in Higher Education, 339-358. https://doi.org/10.1080/03075079.2012.709495.

Maisonneuve, H. (1994). Scientific writing: the choice of references. Cahiers d'études et de recherches francophones/Santé, 4(1), 53-56.

Nicoll, L. H., Oermann, M. H., Chinn, P. L., Conklin, J. L., Amarasekara, S., \& McCarty, M. (2018). Guidance Provided to Authors on Citing and Formatting References in Nursing Journals. Journal for nurses in professional development, 34(2), 54.

Nur, T., Sabara, H. Z., \& Wekke, I. S. (2018). Teknik Menulis Karya Ilmiah: Dengan 8 Senjata Aplikasi Pendukung Produktivitas Riset. Deepublish.

Saur-Amaral, I. (2011). Towards a methodology for literature reviews in social sciences. investigaçao e Intervençâo em Recursos Humanos.

Schweizer, M. L., \& Nair, R. (2017). A practical guide to systematic literature reviews and metaanalyses in infection prevention: Planning, challenges, and execution. American Journal of Infection Control, 45, 1292-1294. https://doi.org/10.1016/j.ajic.2017.08.004.

Vom Brocke, J., Simons, A., Niehaves, B., Riemer, K., Plattfaut, R., \& Cleven, A. (2009). Reconstructing the giant: on the importance of rigour in documenting the literature search process. Ecis, 9, 2206-2217. University of Michigan Press, Digitalculturebooks.

Wekke, I. S. (2017, November 7). Penyempurnaan Penulisan Skripsi. https://doi.org/10.31227/osf.io/qjxr5.

Wibowo, W. (2013). Menulis Artikel ilmiah yang komunikatif. Jakarta: Bumi Aksara.

Winchester, C. L., \& Salji, M. (2016). Writing a literature review. Journal of Clinical Urology, 9(5), 308-312. https://doi.org/10.1177/2051415816650133. 